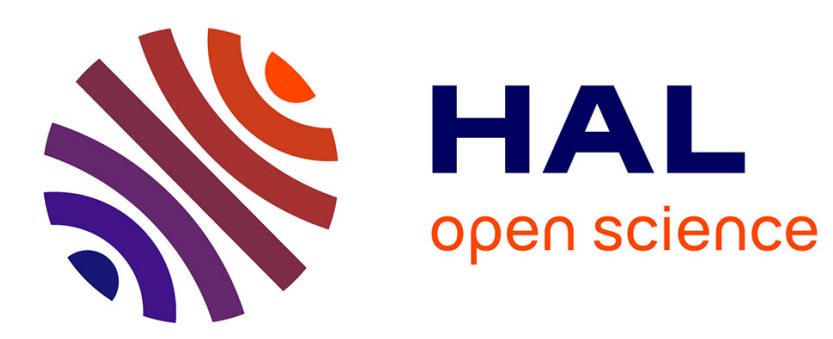

\title{
The Assessment of the Technicality of Computer-Implemented Inventions in Europe
}

Matthieu Dhenne

\section{To cite this version:}

Matthieu Dhenne. The Assessment of the Technicality of Computer-Implemented Inventions in Europe. 2020. halshs-02970592

\section{HAL Id: halshs-02970592 \\ https://shs.hal.science/halshs-02970592}

Preprint submitted on 20 Oct 2020

HAL is a multi-disciplinary open access archive for the deposit and dissemination of scientific research documents, whether they are published or not. The documents may come from teaching and research institutions in France or abroad, or from public or private research centers.
L'archive ouverte pluridisciplinaire HAL, est destinée au dépôt et à la diffusion de documents scientifiques de niveau recherche, publiés ou non, émanant des établissements d'enseignement et de recherche français ou étrangers, des laboratoires publics ou privés. 


\section{The Assessment of the Technicality of Computer-Implemented Inventions in Europe}

\section{Matthieu Dhenne}

« European patents; Patentability; Software; Technical effect; Technical function

Article 52 of the European Patent Convention provides for an exclusion of computer programs. The criterion of technical character (or technicality) is used to assess the patentability of computer implemented inventions. However, this assessment has varied over the years and according to the forum.

According to the European Patent Office (EPO) Guidelines:

\begin{abstract}
"The expression 'computer-implemented inventions' (CII) covers claims which involve computers, computer networks or other programmable apparatus whereby prima facie one or more of the features of the claimed invention are realized by means of a program or programs."
\end{abstract}

Article 52 of the European Patent Convention (EPC) provides for an exclusion of the patentability of computer programs "per se". However, claims most often concern computer programs with technical features. The criteria of technical character-or technicality-which was deducted from a reading a contrario of art.52, has been used to assess whether a claim relates to a computer-implemented invention. The technicality assessment has nevertheless tended to vary over the years and according to the forum. How can we assess the technicality of computer-implemented inventions?

We can distinguish five approaches applied over the years: the incorporation approach: the essential element approach; the technical contribution approach; the further technical effect approach; and the any hardware approach.

\section{The incorporation approach}

Under the incorporation approach, the integration of a thing which is not technical in a new technical set gives birth to a new patentable device. This theory has been used in the computer industry via the concept of a virtual machine. A virtual machine constitutes the illusion of a new machine: it is the use of a known machine according to a new program.

The concept of virtual machine has especially been employed by the Board of Appeal of the Netherlands Patent Office (Octrooiraad), which considered, in a decision rendered on 12 September 1985, that the loading of a new program in a known computer created a new technical device. ${ }^{2}$ The Octrooiraad has subsequently acknowledged that the loading of a new program in a machine gave birth to a new patentable process. ${ }^{3}$ The British practice prior to the entry into force of the Munich Convention reveals a similar position. In a decision rendered in 1970, the Patent Appeal Tribunal admitted an application relating to a machine in which perforated cards realised a method of establishing an international index of trade marks. The machine was known. But the punch cards, on which was found the computer program, were operating in a new way. ${ }^{4}$ The German Federal Patent Court (Bundespatentgericht) has, during a short period, also used the concept of virtual machine. Nonetheless, the Federal Supreme Court (Bundesgerichtshof) intervened later to put an end to this and to reaffirm the core theory (Kerntheorie). ${ }^{5}$

In Decision T-603/89, Technical Board of Appeal (TBA) 3.5.1 of the EPO clarified that the technical contribution of the invention had to be the result of a mutual interaction between the technical and non-technical elements of the invention. This contribution could not refit in a simple juxtaposition of technical features that are known and non-technical features that are new. Rather, the two types of features should interact to give birth to a technical contribution. ${ }^{6}$ In other words: the incorporation approach was implicitly excluded. In any event, the same Board has expressly rejected the concept of virtual machine in Case T-26/86 (Koch \& Sterzel). ${ }^{7}$

\section{The essential element approach}

Under the essential element approach, subject-matter can be considered as technical if its essential element belongs to the field of technology. This is also known as the core theory (Kerntheorie). The approach comprises three steps: decomposition; delimitation; and characterisation. First, the claimed invention must be deconstructed: it is

\footnotetext{
*Attorney-at-Law (Paris bar) Ph.D. (University of Paris 2 Panthéon-Assas)

Guidelines for Examination in the European Patent Office (November 2017), Pt G, Ch.II, para.3.6.

${ }^{2}$ Octrooiraad, Afdeling van Beroep, 12 September 1985, BIE, 1985, p.435.

${ }^{3}$ Octrooiraad, Afdeling van Beroep, 11 May 1987, BIE, 1987, p.174, OJ EPO 1988, p.75; [1988] G.R.U.R. Int. 71

${ }^{4}$ Gevers' Application [1970] R.P.C. 91 PAT

${ }^{5}$ BpatG, 12 August 1987, 19 W(pat) 56/85, Elektronisches Stellwerk [1987] G.R.U.R. 799; BpatG, 10 July 1990, 18 W(pat) 135/89, Schleifverfahren [1991] G.R.U.R. 197; BpatG, 13 February 1992, 23 W(pat) 24/90, Herstellungsverfahren für ein elektronisches Gerät [1992] G.R.U.R. 681; BpatG, 14 June 1999, 20 W(pat) 8/99, Absatzsteuerung Automatische [1999] G.R.U.R. 1078

${ }^{6}$ EPO, TBA 3.4.1, 3 July 1990, T-603/89, Scale-mark/Beattie, OJ EPO 1992, p.230

${ }^{7}$ EPO, TBA 3.5.1, 21 May 1987, T-26/86, Koch \& Sterzel, OJ EPO 1988, p.19.
} 
necessary to find out whether the claimed invention includes a non-technical element that is excluded from patentability. Secondly, one must determine the essential element of the claimed invention. The essential element is an element without which the claimed invention would not exist. Eventually, once this core has been delimited, it must be characterised, and its nature (is it technical or not?) must be examined.

This approach was retained by the German courts for a long time. It was applied to the computer industry field notably in a case concerning a page buffer. The Bundesgerichtshof admitted the technicality of the process in holding that it was essentially technical because the software improved the internal functioning of the computer. ${ }^{8}$ In France, it is clear from the Schlumberger decision that the device implemented by a program may be technical if the program only plays an accessory role. But the device is not technical if the software plays an essential role. ${ }^{9}$ In England, judges have employed a method sometimes designated as the localisation of novelty. ${ }^{10}$ The Statute of Monopolies provided that only a new manner of manufacture could constitute an invention. Some decisions have thus rejected the patentability of inventions whose novelty was not localised in a manufacture. Under this approach, it is appropriate first to locate the novelty and then characterise the nature of the new feature. If novelty is located in a manufacture, the claimed invention is patentable, because its novelty aims at a mechanical purpose. ${ }^{11}$ If novelty is located in a non-technical feature, the claimed invention is not patentable, because its novelty is not aimed at a mechanical purpose. ${ }^{12}$ The localisation of novelty thus allows the identification of the core of the invention to deduce its technical or non-technical nature.

The theory of the essential element was applied by the EPO in two decisions concerning the computer field. The first of them was rendered in Case T-22/85 in 1988. An application had been filed on a method to summarise a document, to store the content obtained, and then to find it by querying the computer. The Examining Division rejected this application on the grounds it was a computer program as such, and thus non-patentable. This decision was confirmed by the Board of Appeal. According to the Board, we cannot consider that the rules intended to establish a procedure for the search for information, in other words, purely intellectual rules, have a technical character. ${ }^{13}$ The TBA 3.5.1 again applied the theory of the essential element in Decision T-38/86 rendered in 1989. An application had been filed on a system for correcting a file as well as detecting and automatically replacing the words of the text exceeding a threshold of misunderstanding for documents intended for the public. The Examining Division rejected the application on the grounds that it covered a computer program as such. The Board confirmed this decision. ${ }^{14}$

\section{The technical contribution approach}

\section{The requirement of a technical contribution as such}

The EPO has introduced the concept of technical contribution in order to be able to understand the contribution of inventions that contain both technical and non-technical features. The concept appeared for the first time in a guideline published in 1985:

"If the claimed subject matter makes a technical contribution to the state of the art, the patentability should not be put in issue for the simple reason that a computer program is involved in its implementation." 15

The technical contribution approach was adopted by the EPO from the middle of the 1980s. The first time was in Decision T-208/84 (Vicom) rendered by the TBA 3.5.1 in $1986 .{ }^{16}$ An application had been filed for an ordinary computer that provided a new function of filtering pictures. This function was performed by software. The Examination Division had rejected this application because the claimed invention was a computer program as such. The Board reversed this decision. The Board excluded the theory of the essential element. The decision states that we should, on the contrary, only search if the whole claimed invention produces a contribution to the state of the art. The TBA 3.5.1 once again adopted the method of the technical contribution in the famous Decision T-26/86. ${ }^{17}$

This approach was first applied by the Boards of Appeal of the EPO. At that time, the national courts were hostile to this type of comprehensive approach of the claimed invention. The German courts were especially hostile and remained for a long time faithful to the Kerntheorie. ${ }^{18}$ This theory continued to be applied by the Bundesgerichtshof after Case T-208/84. ${ }^{19}$ The Bundesgerichtshof finally adopted the concept of technical contribution in the Tauchcomputer decision rendered in 1992. An application had been filed on a device recording diving data, then indicating the decompression time, with a display of the optimum decompression for each dive. The claim included, in

\footnotetext{
${ }^{8}$ BGH, June 11, 1991, Seitenpuffer, OJ EPO 1993, p.241, (1992) 23 I.I.C. 824, note Mr W.

${ }_{9}$ Paris Court of Appeal, 15 June 1981, PIBD 1981, III, p.175.

${ }^{10}$ T. A. Blanco White, Patents for Inventions, 4th edn (London: Stevens \& Sons, 1974), p.22, para.1-211.

${ }_{11}^{11}$ Cobianchi's Application (1953) 70 R.P.C. 199 PAT.

${ }^{12}$ Neva's Application [1968] R.P.C. 481 PAT; see especially 485 and 486.

${ }^{13}$ EPO, TBA 3.5.1, 5 October 1988, T-22/85, Summary and search for documents/IBM, OJ EPO 1990, p.12

${ }^{14}$ EPO, TBA 3.5.1, 14 February 1989, T-38/86, Text processing/IBM, OJ EPO 1990, p.384.

${ }^{15}$ Guidelines for Examination in the European Patent Office (March 1985), Pt C, Ch.IV, para.2.1

${ }^{16}$ EPO, TBA 3.5.1, 15 July1986, T-208/84, Computer-related invention/VICOM, OJ EPO 1986, p.14.

${ }^{17}$ EPO, TBA 3.5.1, 21 May 1987, T-26/86, X-ray apparatus/KOCH \& STERZEL, OJ EPO 1988, p. 19.

${ }_{18}^{18}$ BpatG, 3 February 1987, 17 W (pat) 62/85, Elektronisches Kurvenzeichengerät, OJ EPO 1988, p.59.

${ }^{19}$ BGH, 12 December 1989, Computerträger [1990] G.R.U.R. 594, note Mr Brandi-Dhorn.
} 
addition, a depth gauge, a memory and a converter, all focused on the indicator capable of automatically providing the parameters of the decompression. The application of the core theory, which had been retained in appeal, was rejected by the court. According to the Supreme Court, the judges had not correctly interpreted the claim, because they were focused on the intellectual method, without taking account of the technical means. It was thus considered that the claimed invention, taken as a whole, was technical. It included a contribution to the state of the art. The contribution lay in the cooperation of the technical features (the diving device) and non-technical features (the method and the computer program) to achieve the technical result (the display of information relating to the decompression). ${ }^{20}$

The approach based on the technical contribution has the purpose of concentrating the assessment of the technicality on the result of a combination of means and not on the combined means in themselves. This has been particularly auspicious for the patentability of CII. Nonetheless English and French case law offers examples of revocations based on the technical contribution. The decision rendered in the Merrill Lynch case was the first British example. An application had been filed for a system of stock exchange transactions able to analyse the orders of purchases and sales of customers, according to a given criterion. The satisfaction of this criterion resulted in the automated operation of the transaction. The Court of Appeal rejected this application by referring to Case $\mathrm{T}-208 / 84$, judging that the claimed invention contained no technical progress. ${ }^{21}$ However, in this case, the Court of Appeal confused the technical contribution with the requirement of a technical progress. This interpretation was incorrect. The TBA 3.5.1 never required any technical progress. The only requirement was to seek a contribution to the state of the art, which could not be a progress and could even be a regression.

The precedent of Merrill Lynch led the British judges to retain a strict conception of the technical contribution. ${ }^{22}$ The decision rendered in the Gale case illustrates this trend. An application had been filed for a new method of calculation. The contribution of the invention was a method of calculation of square roots that eliminated the divisions and limited the multiplication of specified binary functions. The contested claim concerned a ROM memory running this method. The Court of Appeal rejected this application by distinguishing between the mathematical procedures and the ROM memory, and judging that the integration of the first into the second does not demonstrate their technicality. Similarly, it was found, in the Aerotel case, that the method of making telephone calls from any phone with a special code was patentable, because the application did rely on a new technical device intended to implement the method. ${ }^{23}$

The French case law presents to our knowledge one example of the use of the technical contribution. ${ }^{24}$ The patent in question concerned a process and a device to access information regarding television programmes. The applicant operated this patent until its expiry date, in several countries, including France, with licences. The patentee introduced an action for infringement claiming that the defendants were implementing his invention. The latter formed a counterclaim for a revocation. The question raised on the validity of the title was the following: was the claimed invention a presentation of information excluded by L.611-10(2) of the French Intellectual Property Code? In the decision of 7 June 2013, the judges indicated that,

"at this stage of the review of the validity, there is no place to search the novelty or inventive step of the invention ... on the other hand, the appreciation of its patentability involves determining the technical contribution that the patent claims".

In this case, it was considered that the patent did not contain any indication proving the existence of a technical contribution. Finally, the judges reiterated firmly, via an obiter dictum, that a computer program does not constitute a patentable technical feature. In addition, the claimed invention was not an invention, because it did not encompass a technical contribution.

\section{The requirement of technical considerations}

The lack of definition of the technical contribution made the determination of that contribution difficult. Therefore, the case law developed a second method intended to facilitate the assessment thereof by focusing on the conception stage of the invention. This approach was introduced by TBA 3.5.1 in its Decision T-769/92 rendered in 1994 (Sohei). ${ }^{25}$ An application had been filed for a computer management system operating by means of a single transfer slip. The claims related both to the computer system and to the method that it implemented. The Examining Division refused this application because the features of the claimed invention consisted of a computer program and a presentation of information that were not patentable as such. The appeal filed against this refusal was based on the involvement of technical considerations at the time of designing the said slip. It was argued that a solution is not carried out in the same way when it is performed by a computer as when it is carried out by a human being. Its conception indicates, in the first case, technical considerations that implied

\footnotetext{
${ }^{20}$ BGH, 4 February 1992, Tauchcomputer [1992] G.R.U.R. 1992430, OJ EPO 1993, p. 250, (1993) 24 I.I.C. 645.

${ }^{21}$ Merrill Lynch's Application [1989] R.P.C. 561 CA, OJ EPO 1988, p.61.

${ }^{22}$ Gale's Application [1991] R.P.C. 305 CA.

${ }^{23}$ Aerotel Ltd $v$ Telco Holdings Ltd [2006] R.P.C.117 CA.

${ }^{24}$ TGI Paris, 7 June 2013, Starsight v Numéricable, RG n ${ }^{\circ}$ 10/08326. See our comment: M. Dhenne, "Reflections on the criterion of the technical contribution" (2014) 108 R.L.D.I. 3575.

${ }^{25}$ EPO, TBA 3.5.1, 31 May 1994, T-769/92, Sohei, OJ EPO 1995, p.525.
} 
technical knowledge. The TBA validated this argument. Thus, it was considered that the technical considerations that were required at the conception stage implied the existence of a technical problem, which resulted in the existence of technical characteristics.

The criterion of technical considerations has rarely been used by the national courts. Two French decisions rendered by the Paris High Court refer to it. In the first one, rendered on 20 July 2006, a patent on a sound processing system through a telephone network was found to be valid, in particular because of the technical considerations that the invention involved. ${ }^{26}$ However, a second decision of the same court rejected the examination of the technical considerations. ${ }^{27}$ The decision rendered by the Bundesgerichtshof in the Logikverifikation case must be also noted. ${ }^{28}$ An application had been filed on a process of circuits logic checks. The court ruled that this type of process was technical. The judges referred to the technical considerations, but only as a complement to the evidence.

\section{The further technical effect approach}

The TBA 3.5.1 for the first time admitted a product claim on a computer program in Decision T-1173/97 rendered in 1998 (IBM I). ${ }^{29}$ The claimed invention related to a method for resource recovery in a computer system. The Examination Division refused the application. The refusal concerned specifically the independent claims 20 and 21, which were directed to a computer program as a product. These claims related to a computer program as such. The examiners concluded that the said claims were inadmissible according to paras (2)(c) and (3) of art.52 EPC. This refusal was set aside. TBA 3.5.1 recalled that it was the lack of technical character that justified the exclusions listed in the article of the EPC. Each feature listed may be the subject-matter of an invention, provided that the said invention produces a technical effect. This technical effect cannot consist of the electrical current produced by inserting the program into the machine. In this case, the technical character depends on the production of a further technical effect.

The criterion of further technical effect has been used several times by the national courts. In France, the concept was used by Paris Court of Appeal in a decision rendered on 20 September 2005. The claimed invention related to a method for preparing an application for the registration of a trade mark. The application was refused by the Director General of the INPI on the grounds that it related to an intellectual method that originated from the field of economic activity. The court upheld this refusal, as the method consisted of the implementation of a non-technical method by known technical means. The invention did not produce any further technical effect.

The Paris High Court referred to the concept of further technical effect in the Free decision rendered on 18 June 2015 . $^{30}$ The claimed invention related to the switching of multimedia sessions from a mobile terminal to local network equipment. The patent notably included: a program-product claim; a claim relating to the source code for the said program; and a claim relating to the support therefor. The court ruled that the three claims were invalid pursuant to art.52(2)(c) EPC. It was considered that a program-product constituted a computer program as such, which was excluded from patentability, and that the achievement of the other two claims did not produce a further technical effect, which was also a barrier to their patentability.

A decision rendered by the Paris High Court on 18 November 2016 also implicitly referred to a further technical effect. In this case, the patent was granted on a management system of applications. The defendant considered that the said system constituted a computer program as such, excluded by art.52(2)(c) EPC. The court accepted this interpretation because it was software for which no technical effect was proven. However, all computer programs produce at least a technical effect in the electrical current that they generate. The court therefore required as well, a fortiori, evidence of a further technical effect in relation to the production of an electric current. $^{31}$

The Bundesgerichtshof has used a concept equivalent to that of the further technical effect: particularity. This criterion was used in the Suche Fehlerhafter Zeichenketten/Tippfehler case. ${ }^{32}$ The claimed invention related to a system for the identification and correction of typing errors in a text recorded by digital means. The application contained a product claim on the computer program making this correction. The Court of Appeal confirmed the rejection on the grounds that the solution lay in a computer program as such. This decision was set aside by the Supreme Court. It was judged that the question was whether the claimed invention included a particularity compared with the current functioning of a computer.

\section{The any hardware approach}

Decision T-931/95 lays the foundation of this approach. ${ }^{33}$ The invention claimed related to a computerised system for controlling pension benefits, which facilitated the management of the said benefits by centralising all contributions. Two claims were put in issue. The first

\footnotetext{
${ }^{26}$ TGI Paris, 20 July 2006, S.A. Cafetel v Co Index Multimedia, RG n ${ }^{\circ} 02 / 11198$.

${ }^{27}$ TGI Paris, 7 June 2013, Starsight v Numéricable, RG n 10/08326. See our comment: Dhenne, "Reflections on the criterion of the technical contribution" (2014) 108 R.L.D.I. 3575

${ }_{28}$ BGH, 13 December 1999, Logikverifikation [2000] G.R.U.R. 498, note J. Betten (2002) 33 I.I.C. 2002, 231.

${ }^{29}$ EPO, TBA 3.5.1, 1 July 1998, T-1173/97, OJ EPO 1999, p.609.

${ }^{30}$ TGI Paris, 18 June 2015, Orange $v$ Free SAS and SAS Freebox, RG n ${ }^{\circ}$ 14/05735.

${ }^{31}$ TGI Paris, 18 November 2016, Xaga v Ewala, RG n ${ }^{\circ} 13 / 11351$.

32 BGH, 17 October 2001 [2002] G.R.U.R. 143; [2002] G.R.U.R. Int. 323.

${ }^{33}$ EPO, TBA 3.5.1, 8 September 2000, T-931/95, Controlling pension benefits system/PBS, OJ EPO 2001, p.1441.
} 
claim related to a method of controlling the system. The second related to the apparatus for implementing this method. The Examination Division refused the application by considering that it concerned a method for doing business, which was excluded from patentability under art.52(1)(c) EPC. TBA 3.5.1 set aside this refusal. According to this Board, the patentability of an invention depends on the type of claim of which it forms the subject-matter. The claim relating to an intellectual method for doing business is strictly to be refused. Such a method exists when the invention claimed serves an economic purpose and does not produce any technical effect. The mere performance of the method by a machine is not sufficient to render that method technical. Rather, the claim relating to an apparatus is inherently technical. In the case in question, the invention relating to an apparatus used to control the pensions system was technical. However, the improvement of the management of pension benefits originated in the field of economics. The inventive contribution of the item claimed was, in other words, not technical and thus non-patentable.

It emerges from Decision T-931/95 that the type of claim, on its own, appears to be able of determining the patentability of an invention. Anything is technical, as long as it is represented in the form of an apparatus. An invention relating to an intellectual method is thus capable of being indirectly claimed in the form of an apparatus. The use of conventional technical means, such as the computer implementation of a method, is sufficient to justify the technical character. However, in a notice of 26 March 2002, the EPO reminded applicants that,

"claims of European patent applications which relate to such methods or merely specify commonplace features relating to the technological implementation of such methods will not be searched if the ... examiner cannot establish any technical problem which might potentially have required an inventive step for it to be overcome".

Decision T 258/03 decisively expanded upon the approach outlined in Case T-931/95. ${ }^{34}$ The invention claimed related to an automatic auction method executed in a server computer. This method had the advantage that it did not require auctioneers to be present at the terminals. The Examination Division refused the application as it deemed that it related to a method for doing business. TBA 3.5.1 set aside this refusal. It was considered that the introduction of known technical means into the claim was sufficient to ensure the technical character of the invention.

In France, only two decisions refer to a test relating to the any hardware approach, namely two judgments of Paris High Court. In the case Infomil v Atos, the court adopted a position in accordance with the decision T-931/95 rendered on 20 November $2007 .{ }^{35}$ The invention claimed related to a method and apparatus for the selective distribution of discount coupons. It was considered that the intellectual method performed by the device did not prevent the invention from being patentable in relation to that device. It was the lack of inventive step that led to the revocation of the patent. Specifically, the aim of the invention was to,

"personalize the various types of tickets by recording the payment and commercial benefits and by issuing various kinds of tickets, whether for payment or benefits which may be other than reductions".

However,

"this different feature is provided within an existing system and does not require any inventive skill; it is sufficient for a computer technician to program this additional feature into the content of one of the files already in place in order to obtain this improvement and thus no inventive step is involved".

On one hand, it emerges from this ground that the claiming of known technical means guarantees the technical character of an invention relating to an intellectual method. On the other hand, the inventive contribution must be technical. In Infomil $v$ Atos, the patent was declared void because this contribution lay in the issuing of commercial benefits. This was therefore not an inventive contribution of technical character.

In England, the Court of Appeal rejected the any hardware approach in the Aerotel case. According to Jacob J, the approach developed by the EPO in Case T-258/03 was not "intellectually honest". Jacob J adopted an approach consisting of four stages: the construction of the claim; the identification of the purpose of the contribution that it contains; the delimitation of the contribution; and the appreciation of the technicality of the contribution. In other words, it retains the approach based on technical contribution. In the Aerotel case, it was considered that the contribution lay in the new device required by the realisation of the method. The invention was essentially technical and therefore patentable. In contrast, in the Macrossan case, the contribution lay in an intellectual method; thus the claimed invention was essentially non-technical, therefore not patentable. ${ }^{36}$ The Court of Appeal, however, brought the English position closer to that of the EPO in the Symbian case. The claimed invention concerned a system of internal interfaces. The application was rejected. The examiner considered that it concerned a computer program as such. This decision was reversed by the Board of Appeal of the UK Patent and Trademark Office (UKPTO). It was considered that the claimed invention engendered a technical effect consisting in the modification of the internal functioning of the computer that produced the implementation of the program. This achievement was patentable, since the system of internal interfaces resulted in a change in the internal functioning of the computer. In other words, the

\footnotetext{
${ }^{34}$ EPO, TBA 3.5.1, 21 April 2004, T-258/03, Auction method/HITACHI, OJ EPO 2004, p.575.

${ }^{35}$ TGI Paris, 20 November 2007, Infomil v Atos, RG N ${ }^{\circ} 01 / 11641$.

${ }^{36}$ Aerotel v Telco [2007] R.P.C. 117.
} 
insertion of an intellectual method into a machine ensures its technicality, and only an invention relating to the treatment of information as such is not technical. This decision rendered by the Board of Appeal of the UKPTO in Symbian was upheld by the Court of Appeal. ${ }^{37}$ In the AT\&T Knowledge Ventures case, Judge Lewison clarified what were the four signposts of the technical effect: if the process has a technical effect outside of the computer; if the technical effect is at the level of the architecture of the computer, in other words if the technical effect is produced without taking account of the data or applications; if there is an increase in the speed or the reliability of the computer; and if the technical problem is overcome and not bypassed. ${ }^{38}$

In Germany, the Bundesgerichtshof adopted an approach similar to that of the EPO in a decision rendered in $2006 .{ }^{39}$ The claimed invention was identical to the one claimed in the Aerotel case. It was a system that allowed telephone calls with any type of device thanks to a special prepaid code. The court found that the presence of known technical means guaranteed the technical character of the invention.

To conclude, this tour of the case law reveals especially the confusion that reigns as soon as the requirement of a technical character arises. Under the pretext of the assessment of technicality, the patent offices and the courts blend this requirement with other grounds of invalidity of the patent, such a lack of inventive step or the insufficiency of the disclosure. But technicality is neither defined or truly characterised. The definition of the concept and the fixing of an appropriate method of assessment should still constitute the prerequisites for its implementation. ${ }^{40}$ It remains to be hoped that in the future the patent offices and the courts will pursue to these tasks so that the field of patentability is no longer a quagmire governed by legal insecurity.

\footnotetext{
${ }^{37}$ Symbian Ltd v Comptroller General of Patents [2009] R.P.C. 1 CA (Civ Div).

${ }^{38}$ AT\& T Knowledge Ventures LP [2009] EWHC 343 (Pat); [2009] F.S.R. 19.

${ }^{39}$ BGH, 7 March 2006, Voraus bezahlten Telefonanrufen [2006] G.R.U.R. 663

${ }^{40}$ See our proposals in M. Dehenne, Technique et droit des brevets (Technics and Patent Law) (LexisNexis, 2016), p.530. These proposals were taken up by the Report of the AIPPI French Group on Patentability of Computer Implemented Inventions (June 2017).
} 